\title{
Black lives matter in Canada too!
}

\section{« Black lives matter » : c'est vrai aussi au Canada!}

\author{
Louise Potvin ${ }^{1}$ \\ Published online: 14 September 2020 \\ (C) The Canadian Public Health Association 2020
}

As pen is set to paper, a summer which on many levels will be recognized as unlike any in our collective memory is drawing to a close. It will certainly have been the summer of COVID-19, this pandemic of a virus that was completely unknown until a few months ago. The virus has spared no country and has revealed shortfalls in healthcare systems. It illuminated the catastrophic deficiencies of Western democracies that allowed notorious incompetents to govern according to their whims, in total ignorance of scientific knowledge and of the manner in which it is produced. It has certainly also been one of repeated heat waves. In North America as in Europe, evidence of climate change has manifested on a daily basis, with records broken for heat on the North American East Coast and for drought on the West Coast (NOAA 2020). It will also be remembered that for the first time in American history and following a spring and summer punctuated by demonstrations to affirm "Black Lives Matter", a Black woman has joined the ticket for one of the two major parties for the presidential election. However, it will have been forgotten that Statistics Canada published a report on the evolution of the socio-economic status of Canada's Black population since the start of the century (Houle 2020). Yet this report is of utmost importance since it shines a light on a significantly overshadowed sector of Canadian society.

In fact, over the course of the spring and summer, while American cities were burning, Canadian institutions and leaders, taking steps in the solidarity movement represented by peaceful demonstrations in Canada's largest cities, had to admit to the existence of systemic racism in the country. The notable exception was Québec, where Premier François Legault, while recognizing that inequalities exist between Black individuals and the

Louise Potvin

louise.potvin@umontreal.ca

1 Centre de recherche en santé publique, Université de Montréal et CIUSSS du Centre-Sud-de-l'île-de-Montréal, Montreal, QC, Canada general population, refused to attribute them to institutional discriminatory practices (Buzetti and Crête 2020). From a public health point of view, the approach that consists of recognizing, flushing out and eradicating systemic racism where it exists saves lives.

In a recent article, Williams et al. (2019) analyze the literature and show how institutional racism, that which is registered and reproduced in the formal and informal practices of our institutions, affects the health of those who are its victims. For them, the lack of access to education and to quality jobs are two fundamental factors by which institutional racism affects health. For Black American minorities, institutional racism is associated from birth with an elevated risk of prematurity and of low birthweight. With regard to cancer, a systematic review reports an association between systemic discrimination and a higher risk of mortality for breast and lung cancers.

The Statistics Canada report (Houle 2020) rightly points out the significant differences that exist in Canada between the Black population and the general population when it comes to education, employment and income. A major strength of the report is to distinguish the data coming from recent immigrants from those of individuals born in the country to immigrant parents (second-generation) or in place for several generations. These distinctions are critical, since, in 2016, immigrants born outside the country made up $71 \%$ of Canada's Black population which comprised a little more than 1 million individuals. Except with respect to immigrant men, the report showed an unfavourable evolution between 2001 and 2016 of the proportion of Black women and Black men having a postsecondary diploma in comparison with the proportion of women and men of the general population who possessed such a diploma. More and more, Black immigrant men are as well educated as men in the general population while Black men and women who are born in the country increasingly lag in obtaining a postsecondary diploma in comparison with men and women of the general population. The report also shows that except for second-generation Black women, the employment rate of Black men and Black women is 
significantly lower than that of their counterparts in the general population, and the gaps are more or less the same for the entire period. With regard to annual median salary, the report indicates that the difference in revenue (about $\$ 20,000$ more annually for men in the general population) between Black men and men of the general population has remained more or less constant for the entire period and for all groups. For second-generation Black women, the wage gap is less and tends to have shrunk since 2001. The report concludes that "Black people generally live in more difficult economic conditions than the rest of the Canadian population" (Houle 2020, p. 31).

What this report shows is that Black people born in Canada have less access to education and to quality jobs than their counterparts in the general population. This puts them effectively in a situation of systemic discrimination. As a result of a collection of institutional mechanisms, formal and informal, our society does not offer Black people the same opportunities as to other Canadians. This situation must be recognized by the authorities and our fellow citizens if we really want to bring about solutions.

In contrast to research in the United States, where numerous studies clearly demonstrate that the fact of belonging to the Afro-American minority is associated with lesser access to healthcare and poorer health, research in Canada shines very little light on the repercussions on health of this systemic discrimination. Recently, Nnorom and her colleagues (2019) highlighted that the healthcare systems in Canada do not collect in a systematic way data concerning race and ethnic origin. It is thus extremely difficult to estimate the inequalities of health associated with belonging to the Black population in Canada.

It is easy for we Canadians to compare ourselves with our neighbours in the South and to congratulate ourselves. Our society is not as violent as theirs, the numbers of individuals from visible minorities not as large, and as a result, the incidences of institutional and systemic violence towards a portion of our citizenry are less flagrant. However, we should not fool ourselves, they do exist: the Statistics Canada report provides an eloquent demonstration. It is time for Canadian researchers to get to work on documenting and analyzing the impacts of systemic racism on the health of Canada's Black populations. Clearly, it is equally true for Canada that "Black lives matter"!

\section{Louise Potvin}

Editor-in-Chief

\section{Éditorial}

Au moment d'écrire ces lignes se termine un été qui s'inscrira comme exceptionnel dans notre mémoire collective, et ce à plusieurs titres. Ç'aura été bien sûr l'été de la COVID-19.
Cette pandémie d'un virus totalement inconnu il y a quelques mois, qui n'a épargné aucun pays et qui a mis en évidence les lacunes des systèmes de soins et les déficiences catastrophiques des démocraties occidentales qui permettent notamment à des incompétents notoires, de gouverner au gré de leurs lubies en ignorance totale des connaissances scientifiques et de la manière dont elles sont produites. Ç'aura été aussi celui des canicules à répétition. Autant en Amérique du Nord qu'en Europe, les dérèglements climatiques se sont manifestés d'une manière quotidienne, fracassant des records de chaleur sur la côte est américaine et des records de sécheresse sur la côte ouest (NOAA, 2020). On se souviendra aussi que pour la première fois dans l'histoire américaine, et suite à un printemps et à un été ponctués par des manifestations pour affirmer que « Black lives matter », une femme noire a fait partie du ticket pour l'élection présidentielle d'un des deux grands partis. On oubliera cependant que Statistique Canada publiait un rapport sur l'évolution de la situation socioéconomique de la population noire canadienne depuis le début du siècle (Houle 2020). Pourtant ce rapport est des plus importants, car il met en lumière une importante zone d'ombre de la société canadienne.

En effet, au cours de l'été et du printemps, alors que les villes américaines s'enflammaient, des institutions et dirigeants canadiens, prenant acte du mouvement de solidarité représenté par des manifestations pacifiques dans les grandes villes canadiennes, ont bien dû admettre l'existence d'un racisme systémique au pays. L'exception notoire étant le Québec, où le Premier ministre François Legault, bien que reconnaissant qu'il existe des inégalités entre les personnes noires et la population générale, a refusé de les attribuer à des pratiques institutionnelles discriminatoires (Buzetti and Crête 2020). D'un point de vue de santé publique, la démarche qui consiste à reconnaître, débusquer et éradiquer le racisme systémique lorsqu'il existe, sauve des vies.

Dans un article récent, Williams et al. (2019) analysent la littérature et montrent comment le racisme institutionnel, celui qui s'inscrit et se reproduit à travers les pratiques formelles et informelles de nos institutions, affecte la santé de ceux qui en sont victimes. Pour eux, le défaut d'accès à l'éducation et à des emplois de qualité sont deux facteurs fondamentaux par lesquels le racisme institutionnel façonne la santé. Pour les minorités noires américaines, le racisme institutionnel est associé dès la naissance à un risque élevé de prématurité et de naissance de petit poids. Pour ce qui est du cancer, une revue systématique rapport une association entre la discrimination systémique et un risque de mortalité plus élevé pour les cancers du sein et du poumon.

Le rapport de Statistique Canada (Houle 2020) fait état justement des écarts importants qui existent au Canada entre la population noire et la population générale pour ce qui est de l'éducation, de l'emploi et du revenu. Une des forces du rapport est de distinguer les données provenant des immigrants récents des personnes nées au pays de parents immigrants ou 
installés depuis plusieurs générations. Ces distinctions sont critiques, car, en 2016, les immigrants nés à l'extérieur du Canada formaient $71 \%$ de la population noire du pays qui comptait un peu plus d'un million de personnes. Sauf en ce qui concerne les hommes immigrants, le rapport montre une évolution défavorable entre 2001 et 2016 de la proportion des femmes noires et des hommes noirs possédant un diplôme postsecondaire en comparaison à la proportion des femmes et des hommes de la population générale qui possèdent un tel diplôme. De plus en plus, les hommes noirs immigrants sont aussi scolarisés que les hommes de la population générale alors que les hommes et les femmes noires qui sont nés au pays accusent de plus en plus de retard dans l'obtention d'un diplôme postsecondaire comparativement aux hommes et aux femmes de la population générale. Le rapport montre aussi que sauf pour les femmes noires de deuxième génération, le taux d'emploi des hommes noirs et des femmes noires est significativement plus faible que pour leur contrepartie de la population générale, et les écarts sont à peu près les mêmes pour toute la période. En ce qui concerne le salaire annuel médian, le rapport indique que l'écart de revenu (environ $20000 \$$ de plus annuellement pour les hommes de la population générale) entre les hommes noirs et les hommes de la population générale est demeuré à peu près constant pour toute la période et pour tous les groupes. Pour les femmes noires de seconde génération, l'écart est moindre et tend à se rétrécir depuis 2001. Le rapport conclut que « les populations noires vivent généralement dans des conditions économiques plus difficiles que le reste de la population canadienne » (Houle 2020, p. 34).

Ce que ce rapport montre c'est que les personnes noires nées au Canada ont un accès moindre à l'éducation et aux emplois de qualité que leurs contreparties de la population générale, ce qui les place effectivement dans une situation de discrimination systémique. À travers un ensemble de mécanismes institutionnels formels et informels, notre société ne leur offre pas les mêmes opportunités qu'aux autres Canadiens. Cette situation doit être reconnue par les autorités et nos concitoyens si l'on veut y apporter des solutions.

Contrairement aux États-Unis où de nombreuses études montrent bien que le fait d'appartenir à la minorité afroaméricaine est associé à un moindre accès aux soins et à une moins bonne santé, la recherche au Canada n'apporte que très peu d'éclairage sur les répercussions de cette discrimination systémique sur la santé. Récemment, Nnorom et ses collaborateurs (2019) soulignaient que les systèmes de santé au Canada ne recueillent pas de manière systématique les données concernant la race et l'origine ethnique, ce qui rend extrêmement difficile d'estimer les inégalités de santé associées au fait d'appartenir à la population noire canadienne.

Il est facile pour nous Canadiens, de se comparer à nos voisins du sud et de s'autocongratuler. Notre société n'est pas aussi violente que la leur, les personnes issues des minorités visibles pas aussi nombreuses, et de ce fait, les violences institutionnelles et systémiques envers une partie de nos concitoyens sont moins flagrantes. Il ne faut cependant pas se leurrer, elles existent : le rapport de Statistique Canada en fait une démonstration éloquente. Il est donc temps pour les chercheurs canadiens de se mettre à l'ouvrage et de documenter et analyser les impacts sur leur santé du racisme systémique envers les populations noires du Canada. Bien évidemment, c'est vrai aussi pour le Canada que « Black lives matter »!

Louise Potvin, Ph.D.

Rédactrice en chef

\section{References/Références bibliographiques}

Buzetti, H., \& Crête, M. (2020). Le racisme condamné à Québec et à Ottawa. Le Devoir, 3 juin 2020. https://www.ledevoir.com/ politique/quebec/580031/quebec-solidaire-demande-un-plan-delutte-contre-le-racisme. Accessed 14 Aug 2020.

Houle, R. (2020). Changes in the socioeconomic situation of Canada's Black population, 2001 to 2016/Évolution de la situation socioéconomique de la population noire au Canada, 2001 à 2016. Ottawa: Statistics Canada. https://www150.statcan.gc.ca/n1/pub/89657-x/89-657-x2020001-eng.htm (English version, page 31) and https://www150.statcan.gc.ca/n1/fr/pub/89-657-x/89-657x2020001-fra.pdf?st=olXm9DNq (French version, page 34). Accessed 14 Aug 2020.

Nnorom, O., Findlay, N., Lee-Foon, N. K., Jain, A. A., Ziegler, C. P., Scott, F. E., Rodney, P., \& Lofters, A. (2019). Dying to learn: a scoping review of breast and cervical cancer studies focusing on Black Canadian women. Journal of Health Care for the Poor and Underserved, 30, 1331-1359. https://doi.org/10.1353/hpu.2019. 0100 .

NOAA (National Oceanic and Atmospheric Administration) (2020). National climate report - July 2020. https://www.ncdc.noaa.gov/ sotc/national/202007. Accessed 14 Aug 2020.

Williams, D. R., Lawrence, J. A., \& Davis, B. A. (2019). Racism and health: evidence and needed research. Annual Review of Public Health, 40, 105-125. https://doi.org/10.1146/annurev-publhealth040218-043750.

Publisher's note Springer Nature remains neutral with regard to jurisdictional claims in published maps and institutional affiliations. 